Article

\title{
The Magic and Science of Grimm: A Television Fairy Tale for Modern Americans
}

\author{
Julianna Lindsay \\ Texas Historical Commission, 1738 FM 2705, Mexia, TX 76667, USA; ulianna.Lindsay@thc.state.tx.us \\ Academic Editor: Claudia Schwabe \\ Received: 11 March 2016; Accepted: 23 May 2016; Published: 27 May 2016
}

\begin{abstract}
The National Broadcasting Company's (NBC) Grimm uses fairy tales and an altered history to explore modern issues in American society such as environmental concerns, individuality, and social and cultural change through magic and magic-tinged science. Worldwide chaos and strife are easily explained as part of the Grimm universe (Grimmverse) through Wesen (humanoid creatures who share characteristics with animals such as appearance and behavior), leading to a more united view of humanity and equality of human experience. Evil is often more scientifically explained, and what may appear random within our reality becomes part of a pattern in Grimm. Grimm gives its American audience a form of societal unity through historic folklore and a fictional explanation for the struggles Americans perceive to be happening within their own society as well as in other parts of the world.
\end{abstract}

Keywords: fairy tale; television; Grimm; technology; science; magic realism

\section{Introduction}

Fairy tales evoke a variety of images in American culture, often associated with Disney, Shrek, the brothers Grimm, or even bedtime stories. These stories explore cultural themes such as good versus evil through magical, alternative worlds which mirror our own lives and physical space [1]. Marie-Catherine d'Aulnoy coined the term fairy tale in 1697 when she published her first volume of tales, leading to a new classification for these stories [2]. Although fairy tale origins are disputed [3,4], they are a tradition that dates back to at least three centuries with many scholars believing they extend even further back in European storytelling traditions [1,5].

Simon Bronner studied fairy tales in American culture and the influence the Brothers Grimm had on the American perceptions of these stories. Jacob and Wilhelm Grimm have one of the largest and most famous fairy tale legacies. The Grimms have two connections to Americans-through the popular culture view of their fairy stories as children's tales and the academic view of the Grimms linked to national theory. In American popular culture, the Grimm tales are believed to have a universal appeal. To Americans, the Grimm tales forge a connection to nature, solidify a national or group unity, and provide wish fulfillment. The peasants in the stories became folk heroes akin to the American farmers, tying peasants to the Jeffersonian ideal of a small farm and living off the land that permeated American culture by the time these stories reached North American shores [6,7]. Bronner noted that although the Grimm stories are the paramount example of fairy tales in American culture, Hollywood's adaptations of stories into films such as Snow White or Cinderella rooted these stories more deeply into the nation's consciousness. In America, the Grimm fairy tales had gained popularity as children's morality tales and Americans postulated that they would excite the imaginations of children living in what they considered a dull, industrial age [6]. This emphasis on morality and imagination bled into the Disney films involving fairy tales, further influencing future generations. In turn, the values present of tolerance and diversity helped fuel the social and cultural revolutions of the 1960s further extending the influence the Grimm stories, or versions of these stories, had on Americans [8]. 
Each retelling of fairy tales carries with it the values of the culture in which the tale is reimagined and the time in which it is produced [8]. According to Tatiana Podolinská and Milan Kováč, there are two types of reasoning or ways to see reality-mythical or logical. Podolinská and Kováč note that belief, magic, logic, and causality intersect differently within each culture and person [9]. However, Barbara A. Strassberg posits that magic, religion, science, technology, and ethics are the four categories which coexist within every culture and society mixed together in varying amounts, evolving over time. Strassberg writes that magic and religion are based in faith, whereas science and technology rely on the observable and testable. These elements correspond to different individual, social, and cultural needs. None of the four elements are interchangeable according to Strassberg. She states that magic in our modern society is often found in lucky numbers, lucky charms, horoscopes, or paranormal beliefs. Religion is often viewed as personal within. Strassberg believes our public discourse has shifted away from private beliefs to instead an increasing interest in science, a movement often fueled by the belief in becoming an informed consumer. Technology has become pervasive in individual lives and society now expects it as part of everyday life. Ethics have become a mixture of universal rules and personal morals. She writes that the evolution of these components happens at varying rates within each culture and society. Individuals tend to initially resist change within any of these elements through a cognitive, emotional, or actionable response, but once acceptance happens, it can spread into other areas of the culture. These seemingly contradictory elements exist within each person's reality without conflict due to the internal perceptions of reality and the uniqueness of cultural and personal filters [10].

Fantasy genres such as fairy tales often engage in reinvented reality and history using varying amounts of magic, science, technology, and ethics. Claudia Schwabe theorizes that recent televisual adaptations of fairy tales create a magic realism where the story is set in our current reality, but with the addition of a supernatural element which is not separate from, but rather intertwined with our world. The fantasy in fairy tales is used to explore questions such as the place of technology in society, individualism, or evil through the vehicles of magic coupled with modern science [11]. Recently, popular culture has seen an increase in science fiction, fantasy, and fairy tales in film and television. Movies such as Snow White and the Huntsman or television series such as Once Upon a Time have captivated new audiences by retelling old stories. One of these new stories is Grimm, a television series which premiered on NBC in 2011, and is described on NBC's website as a procedural drama inspired by the classic Brothers' Grimm fairy tales. The hero, Nick Burkhardt, discovers he is descended from a line of Grimms (people who can see and who fight Wesen: humanoid creatures who can look human or like anthropomorphic animals). Nick befriends a former suspect, Eddie Monroe, who is a reformed, now vegetarian, Blutbad (wolf-like Wesen). As the show progresses, a cast of Wesen such as Rosalie Calvert, a Fuchsbau (fox-like Wesen) are added to Nick's group of friends. Wesen usually look human to the majority of people, but they can woge (change into their animal-like state) at will. According to Monroe, Wesen can be seen as Wesen if they wish to be seen, but Grimms can see Wesen when they do not wish to be seen. Wesen can lose composure when emotional, and this lack of control allows Grimms to see their true form. In response, if a Wesen looks into the eyes of a Grimm when woged, they see reflected back to themselves their true form and bottomless darkness in the eyes of the Grimm [12-14]. These Wesen in the Grimmverse (Grimm universe) are the origin of monsters in fairy tales, according to the show [14]. In much the same way that Angel and Buffy in Buffy the Vampire Slayer became unlikely allies, Grimm pairs Nick and Monroe in the Grimmverse together as a vehicle of humor, social commentary, and interest. Grimm focuses on the current vogue for dark fairy tales, mixing gothic horror akin to Frankenstein; or, The Modern Promethus with an emphasis on science and pseudoscience employing the view that fairy tales cover the primal urges of humans, suppressed by society [15]. These urges are shaped into Wesen, whose natural, or pseudoscientifically defined behaviors within the writings of the Grimm books compiled by Grimm ancestry often belie a dark side of human nature. These behaviors are linked to the type of Wesen and the behavior of the corresponding animal they resemble, such as Blutbads liking to run in packs and hunt much like wolves. In Grimm, Wesen are the monsters hiding invisibly within humanity. 
Americans have become increasingly concerned with sociocultural, political, economic, and environmental issues such as immigration, religious strife, the domains of religion and science, terrorism, economics, civil rights, religious freedom and boundaries, racial upheaval, societal evolution, and the place of the United States in the global order. American politics and culture is seemingly increasingly polarized in recent years, with little end in sight. With the recent rise in fairy tale related movies and television shows, this author questioned whether or not the retelling of fairy tales in NBC's Grimm could be a way for American audiences to regain emotional control in a modern and changing world amidst social and cultural anxieties through temporarily retreating into a safe space of making monsters into scientifically explained species and including just enough magic to retain wonder and interest in audiences. Grimm becomes a recast reality of magic realism [11] where magic only retains a small place in the present and science instead becomes the explanation for many of the world's myths and criminal problems. This retelling allows the story to remain enjoyable to the audience as a metaphor to everyday concerns [11].

\section{Results and Discussion}

The creators and writers of Grimm have mixed modern science with traditional fairy tale magic and magic realism [11] to create their Grimmverse. Science is most prominent in Grimm through genetics. Genetics are a prominent explanation for monsters and heroes in the stories and fighting monsters or being monsters becomes inherited. Grimm-ness is a trait which is not passed on to every descendent of a Grimm. Nick's ability to see Wesen is explained as an extra cone in his retina, referencing 2012 research on Tetrachromacy [14,16,17], a trait which may also explain the deep blackness of a Grimm's eyes as reflected to Wesen when they are transformed into their animal form. A Grimm's retinas might be interpreted to produce a magical version of the tapetum lucidum, the reflective surface on the back of the eyes of nocturnal animals. Wesen also have inherent behavioral and phenotypic characteristics. Only some Wesen behaviors can be changed through enormous self-discipline. Several Wesen traits are explained through the magnification of natural human biological processes or elements. Dämonfeuer (dragon type Wesen), for example, are able to metabolize their body fat through ketosis, mix the fat into an aerosol, and then spew the vapor into the air where it is ignited. In development, most Wesen are unable to transform until a version of Wesen puberty, making their woge biological in origin as opposed to a more magical metamorphosis such as a vampire bite. Hexenbiests (witch-like Wesen) are some of the most supernatural of Wesen, able to produce spells and engage in reality-defying actions. However, Hexenbiests all possess a certain amount of similarities with an attractive phenotype, inherited personality traits such as loyalty to those for whom they work, pathological deceit, and a mark under the tongue. Through a reliance on the biological origins of Wesen behavior, many nefarious events and personages become scientifically explained in the Grimmverse [14].

Through the use of science in combination with magic and magic realism [11], Grimm addresses several modern American sociocultural, environmental, historical, and occasionally economic concerns. Social change is explored in Grimm through a variety of means, including using the cultural and ancestral past in the present where fairy tales become informants on present of reality, and ancestors are protectors of the present. One way ancestors become protectors is through actions such as telling cautionary tales or writing the Grimm volumes, books written by Grimms from the Grimmverse, on Wesen. There is an acceptance of the ancestral Grimm tales as truth and the ancestor experience as an invaluable resource. Each tale is written and illustrated in the original Grimm's native language, and translations are often provided by Nick's Wesen friends Monroe or Rosalie, who often make comments about the language and a time they recall using or learning it. Monroe and Rosalie also often discuss the Wesen in the stories and their own ancestral ties to the accounts, rumors, or objects from the Grimm narrative. There is much emphasis throughout the show text of how Nick is different than past Grimms because unlike the Grimm stories, he does not kill every Wesen and instead judges each individual by moral character and actions. This is an emphasis on how Nick is a product of social change: his enlightened, modern, and accepting attitude as opposed to his ancestor's specist 
attitudes. However, when it suits the situation, Nick will bring up past Grimm reputation, titles, or stories to frighten or intimidate a Wesen he is questioning, interrogating, or fighting. Although his character attempts a more moral stance on killing Wesen, he still uses the fear his ancestors instilled in the Wesen community through terror and murder as a means of obtaining what he wants at the time if he deems it necessary. The reputation of his ancestors being a feared and terrible force against Wesen is a convenient truth Nick can accept or deny depending on the situation. Monroe often uses his ancestral past, connections, and family stories as a means to help Nick. Monroe waxes poetic at times while describing something from his lineage, engaging in strong nostalgia about the past, his ancestry, or Germany. Another means of ancestor protection is when Nick's mother appears in the story and saves his life. Nick had thought his mother was deceased, and he was raised by his Aunt Marie. In Season 1 Episode 22, his mother, Kelly Burkhardt, reappears in his life just as he is attempting to fight one of the men who caused the car crash in which he thought she had died. Although she is later killed in Season 4 Episode 21, he relies heavily on her for a time and her experience and protection are invaluable [14].

Class is another social issue which appears in Grimm. Wesen are often organized in a hierarchy of prey and predator. Wesen also have the overarching hierarchy of institutions like the Wesen Council which controls Wesen affairs. Globally across humans and Wesen are the ultimate authority: the Royals, seven royal families which control the world politics, society, and economics. The Wesen Council is reminiscent of the Watcher's Council in Buffy the Vampire Slayer, although not as directly involved in the storyline. The introduction of this particular hierarchical feature may be on the part of Greenwalt who was co-executive producer on Buffy prior to Grimm [14]. Prey and predator are arranged in relation with the faunal equivalent of the Wesen. For example, Lausenschlange (a snake-like Wesen) are often predators of Maushertz (mice-like Wesen). Blutbads who mirror wolves are traditional hunters and enemies of Bauerschwein (pig-type Wesen) in clear reference to the "Three Little Pigs". The Wesen hierarchy of prey and predator and Wesen's knowledge of the other types of Wesen is often based on their species' placement within the hierarchy influencing how that type of Wesen subjectively defines the positivity or negativity of the other Wesen and the type of relationship the types of Wesen may experience based on their perceived status. Humans who do not know about Wesen exist in a nearly separate realm from this Wesen hierarchy, while Kehrseite (those humans who cannot see Wesen but know they exist) become integrated into Wesen affairs as tangential to Wesen society. The royal families also have a part in the hierarchy, but as Kehrseite who are rulers of the world. Wesen are obligated to obey or at minimum respect Royals, no matter where the Wesen or Royals may live. Instead, Wesen are most directly affected by the Wesen Council, a group which determines most international Wesen affairs [14].

Grimm addresses environmental issues as well, especially those prominent in current American popular culture such as extinction. In Grimm, there are several instances of rare Wesen: Wesen which were often hunted to near extinction. Glühenvolk are one example of an endangered Wesen. Glühenvolk are a Wesen that have a glowing skin and alien features. This Wesen craves cow ovaries when pregnant, giving a Grimm explanation to alien sightings and the cattle mutilation found in American conspiracy theory and popular culture. The Glühenvolk skin is sold for high prices on the black market, making it a very secretive Wesen living in constant fear of discovery. When Nick encounters a man and his pregnant wife who are Glühenvolk, Monroe and Rosalie are shocked believing those Wesen no longer existed-hunted to extinction. Endangered species and extinction are a hot topic in many parts of the world, but especially dear in places like the Pacific Northwest where the spotted owl made such a strong impression upon American cultural awareness of deforestation and its effects [14].

There is also an emphasis on the forests surrounding Portland. The forest is the opposite of society, urbanity, and civilization. Forests are the natural world. Woodlands can also be seen as dangerous, unpredictable, magical, and challenging. Grimm, set in Portland, becomes a place of lush forests echoing the towering Black Forest of German legends. Periodically, this wood becomes the setting of 
stories which typically involve some of the wilder or often magical elements of the characters, where, for example, Wesen can roam freely and chase prey. However, the forest itself in Grimm is not presented as a place of constant fear or inherent danger. The forest is simply another setting. The majority of crimes and major occurrences of brutality through monsters are in cities, exposing a primal order to nature in Grimm in opposition to increased urban disorder in the Grimmverse. This is perhaps turning the traditional fairy tale forest on its head, where the home or village was the safe place and the wilderness was the wild space of danger. This may also be due to the popularity of the forest in American culture as a space that is inherent to American national and historic identity and locally important to the Pacific Northwest as an identifier of place and space [14,18].

Grimm lauds originality and individualism, important American values, through its storylines and character plots. Although Wesen have certain cultures in conjunction with biologically driven urges, they are also not victims of their nature entirely. Wesen are subject to their wills, emotions, and reason. Monroe, for example, chooses to not engage in hunting or eating meat since he does not approve of how he behaves when doing either. He also chooses to pursue a relationship with a Wesen of another type, Rosalie, despite inter-Wesen relationships being looked down upon by many within the community. The relationship between Nick and Monroe is also contrary to the established social order, and Nick's choosing to relate to Wesen as friends or even trusted confidants attests to his individuality and uniqueness, his individual agency being retained through his own decisions [14].

Individual choice and agency as well as inter-Wesen relationships all have strong correlations to American social issues of race, class, gender, and sexual orientation debates as well as strong traditional correlations to American beliefs in individualism and self-agency. Grimm unites human persons against a common nefarious element of Wesen as the enemy and shows that although there is violence and confusion in the world, even ordinary people can make a difference through personal choices. The explanation of evil Wesen as a source of woe in the world brings an order to chaos. Grimm consistently ties past events such as the Third Reich to present events in the Grimmverse with as the rise of the extremist group Black Claw, giving the present a thread of consistency with crime and terror in world history. Humans are faced with needing to unite to overcome Wesen problems, problems most do not even know about. This connection binds all Kehrseite with a heritage of fighting and suffering at the hands of Wesen perpetrated violence. In a present world where Americans view many religious, political, and ethnic groups as hopelessly fractured, Grimm's use of Wesen as an author of world troubles explains how the enemy is actually a fantastical element as opposed to human.

Wesen are also noted as responsible for several violent and non-violent crimes from reality. As Americans were recovering from the real estate crash in 2008, "Plumed Serpent" addressed the copper thefts from abandoned homes that rose throughout the country as potentially being related to Dämonfeuer who collected copper and other shiny metals they traditionally hid in caves. Rosalie and Monroe are victims of Wesen extremists, the Secundum Naturae Ordinem Wesen who are akin to the Ku Klux Klan-frowning upon inter-Wesen relationships and going to the extremes of murdering Wesen who engage in these relationships. Black Claw is another Extremist Wesen group that is seeking to put Wesen in charge of the world and to out Wesen to humanity. Adolf Hitler was a member of Black Claw in the Grimmverse, and Black Claw is blamed for many acts of mass murder, genocide, and terrorism. As Americans become increasingly fearful of global violence and religious extremism, Grimm puts a Wesen face on many crimes as opposed to the human face that adorns the perpetrators in reality, For a short time, an extremely contentious topic in American culture, politics, and media becomes othered in fantasy to become not an American problem or even a human problem, but instead a global conspiracy of non-human origin. Secundum Naturae Ordinem Wesen become Black Claw members, not simply home-grown human bigots. The Grimmverse allows Americans to retain more idealism, even if it is not utopic. The world suddenly becomes less haphazard and more patterned [14]. 


\section{Conclusions}

Through televisual media, Grimm allows audiences a chance to explore societal issues and fears within its stories. Fairy tales are shaped by the time and place they are retold [19], giving this retelling of the Grimm stories its own uniqueness. Grimm matters because it provides a window on the current American fears of world disorder and social upheaval giving viewers and researchers a small piece of the larger societal and cultural concerns. The storylines and Grimmverse can be seen as reactions to fears about the instability of the global or domestic economies, wars, and other worrisome events over which individuals have no control. Instead, control in the Grimmverse comes through personal action coupled with a scientific or primarily genetic relationship between problems and solutions. Control is gained through safely examining social issues through fantastical storylines emphasizing personal onus of action. In order to counteract the inexplicable, magic is drawn into the story to provide just enough wonder to keep events interesting and perhaps as an acknowledgement that not every event or behavior has a clear explanation. Past actions of Grimms bring current responsibility for solving problems to Nick based on cultural value systems present in the actions of ancestral individuals and within precursor movements. These heritage values [20] also comment on the deep concerns individuals in the present have. By drawing on the past values, the characters bring the perceived success of their ancestors to the crises of today. The larger success of Grimm demonstrates a modicum of cultural agreement or resonance with these fears and ways in which Americans either choose to engage in escapism from the anxieties or wishfulness at the simplicity of the Grimmverse blame and solution.

Conflicts of Interest: The author declares no conflict of interest.

\section{References}

1. Asma Ayob. “The Mixed Blessings of Disney's Classic Fairy Tales.” Mousaion 28 (2010): 50-64.

2. Jack Zipes. "The Meaning of Fairy Tale within the Evolution of Culture." Marvels E Tales: Journal of Fairy-Tale Studies 25 (2011): 221-43.

3. Ruth B. Bottigheimer. "Fairy Godfather, Fairy-Tale History, and Fairy-Tale Scholarship: A Response to Dan Ben-Amos, Jan M. Ziolkowski, and Francisco Vaz da Silva." Journal of American Folklore 123 (2010): 447-96. [CrossRef]

4. Dan Ben-Amos. "Introduction: The European Fairy-Tale Tradition between Orality and Literacy." Journal of American Folklore 123 (2010): 373-76. [CrossRef]

5. Francisco Vaz Da Silva. “The Invention of Fairy Tales.” Journal of American Folklore 123 (2010): 398-425. [CrossRef]

6. Simon J. Bronner. Following Tradition: Folklore in the Discourse of American Culture. Logan: Utah State University Press, 1998.

7. Lucy R. Lippard. The Lure of the Local: Sense of Place in a Multicentered Society. New York: The New Press, 1998.

8. Tracey Mollet. "With a smile and a song ... 'Walt Disney and the Birth of the American Fairy Tale." Marvels \& Tales: Journal of Fairy-Tale Studies 27 (2013): 109-24. [CrossRef]

9. Tatiana Podolinská, and Milan Kováč. “'Mythos' Versus 'Logos': Strategies of Rationalization at the Boundaries of Two Worlds in the Conceptions of Supernatural Beings in Slovak Countryside." Dialogue and Universalism 12 (2002): 85-99.

10. Barbara A. Strassberg. "Magic, Religion, Science, Technology, and Ethics in the Postmodern World." Zygon 40 (2005): 307-22. [CrossRef]

11. Claudia Schwabe. "Getting Real with Fairy Tales: Magic Realism in Grimm and Once Upton a Time." In Channeling Wonder: Fairy Tales on Television. Edited by Pauline Greenhill and Jill Terry Rudy. Detroit: Wayne State University Press, 2014, pp. 294-315.

12. NBC. "Grimm." Available online: http://www.nbc.com/grimm (accessed on 16 May 2016).

13. Wikipedia. “Grimm (TV Series)." Available online: https://en.wikipedia.org/wiki/Grimm_\%28TV_series\%29 (accessed on 16 May 2016).

14. Grimm. Directed by David Greenwalt, Jim Kouf, and Stephen Carpenter (Creators). BNC, 2011. 
15. Kristiana Willsey. "New Fairy Tales are Old Again: Grimm and the Brothers Grimm." In Channeling Wonder: Fairy Tales on Television. Edited by Pauline Greenhill and Jill Terry Rudy. Detroit: Wayne State University Press, 2014, pp. 210-28.

16. Wikia. "The Grimm Wiki." Available online: http://grimm.wikia.com/wiki/Grimm (accessed on 29 February 2016).

17. Veronique Greenwood. “The Humans with Super Human Vision.” Discover Magazine, 18 June 2012. Available online: http:/ /discovermagazine.com/2012/jul-aug/06-humans-with-super-human-vision (accessed on 26 May 2016).

18. Marco R. S. Post. "Perilous Wanderings through the Enchanted Forest: The Influence of the Fairy-Tale Tradition on Mirkwood in Tolkien's The Hobbit." Mythlore 33 (2014): 67-84.

19. Laurence Talairach-Vielmas. "Beautiful Maidens, Hideous Suitors: Victorian Fairy Tales and the Process of Civilization." Marvels E Tales: Journal of Fairy-Tale Studies 24 (2010): 272-96.

20. George Smith, Phyllis Mauch Messenger, and Hillary Soderland. "Introduction." In Heritage Values in Contemporary Society. Edited by George Smith, Phyllis Mauch Messenger and Hillary Soderland. Walnut Creek: Left Coast Press, 2010, pp. 46-48.

(C) 2016 by the author; licensee MDPI, Basel, Switzerland. This article is an open access article distributed under the terms and conditions of the Creative Commons Attribution (CC-BY) license (http://creativecommons.org/licenses/by/4.0/). 